\title{
Parvati Raghuram*
}

\section{Which Migration, What Development: Unsettling the Edifice of Migration and Development}

\author{
Paper presented at the conference on 'Transnationalisation and \\ Development(s): Towards a North-South Perspective', Center for \\ Interdisciplinary Research, Bielefeld, Germany, May 31 - June 01, 2007
}

COMCAD Arbeitspapiere - Working Papers

No. 28,2007 
Raghuram, Parvati: Which Migration, What Development: Unsettling the Edifice of Nigration and Development, Bielefeld: COMCAD, 2007

(Working Papers - Center on Migration, Citizenship and Development; 28)

The COMCAD Working Paper Series is intended to aid the rapid distribution of work in progress, research findings and special lectures by researchers and associates of COMCAD. Papers aim to stimulate discussion among the worldwide community of scholars, policymakers and practitioners. They are distributed free of charge in PDF format via the COMCAD website.

The opinions expressed in the papers are solely those of the author/s who retain the copyright. Comments on individual Working Papers are welcomed, and should be directed to the author/s.

University of Bielefeld

Center on Migration, Citizenship and Development (COMCAD)

Postfach 100131

D-33501 Bielefeld

Homepage: http://www.comcad-bielefeld.de 


\section{Introduction}

In recent years migration has been rediscovered as a key intervening apparatus in facilitating development, offering a route to mitigating deepening global inequalities. As a result a range of institutions, and individuals have become involved in studying, fostering and more recently critiquing the range of programmes and practices that can be swept under the migrationdevelopment nexus (Nyberg-Sørensen et al., 2002). A quick look at the website hosted by the UN on migration and development alerts us to the multiple actors, sites and spaces in which these debates are being enacted. In September 2006 one strand of these discussions culminated in a United Nations High-level dialogue on migration and development. The meeting was preceded by a range of events - national governments hosted their own workshops where 'experts' were invited to help frame their statements to the high-level dialogue; regional meets discussed the configurations of migration and development in particular spatial settings; NGOs lobbied to have their voices heard on a range of perspectives. Thus there is a wide array of activities, perspectives and places in which the migration-development nexus has come to be debated1.

Yet underlying these variations lie a certain similarity, a set of discourses, spatial and temporal ontologies and distinctive registers through which the nexus is treated. Both migration and development are configured in familiar and preset ways so that particular forms of migration and certain kinds of development come to be hypervisible in this debate occluding other imaginaries of what might be contained within the interrelationships between migration and development. This paper is a first attempt at unsettling some of the emerging normativities in discussions of migration and development. The rest of the paper is divided into four sections. The next section brings attention to the dominant ways in which the association between migration and development is currently imagined. It then points to methods for unsettling this relationship. The second and third sections begin to unpack the notions of migration and development respectively. The final section offers a conclusion.

\footnotetext{
${ }^{1}$ However, in this study I am only sweeping into the frame those ideas/practices and studies that occur in certain hegemonic discussions of 'migration and development'. There are undoubtedly exceptions to these formations and I have mentioned these at some points. It has, however, not been possible to exemplify all the issues I address here due to the lack of space. Where examples have been provided they often draw on Indian emigration to the UK, the area I know best. Thus I too reproduce some of the spatial and temporal occlusions which I critique in the paper!
} 


\section{Migration and development - the contours of visibility}

In this section I begin by laying out what I see to be some reasons for the firm linking between migration and development. I then explore some of the ways in which the relationship between migration and development have thus far been conceptualised. I do this in order to highlight some of the dominant contours of the frameworks within which this nexus is currently researched. These I argue are the hypervisibilities that shape current discussions on the topic.

\section{Why migration and development now}

Migration and development have for long been interlinked. In the first half of the twentieth century although most of the discussions focussed on the role of rural-urban migration in development, analysis of international migration and its developmental effects too were recognised in diplomatic as well as academic circles. Thus, even as far back as 1906, the German ambassador to the United States in his discussion of German emigration to South America commented that such communities through their consumption of German manufactured products become 'an intermediary of increased traffic exchange between the new and the old countries' (Von Sternburg, 1906: 647-648; emphasis in original). The US Committee on Scientific Aspects of Human Migration (of the American Social Science Research Council) too included economic aspects of migration as one of 6 key themes around which to study migration (1927), a field that they identified as containing 'magnificent possibilities' (p. 258). Moreover, even in the 1950s and 1960s, in what some might call the heydays of developmentalism, the relationship between migration and economic development were concerns for people around the world. Treatises were written on the role of migration in development in a variety of contexts ranging from the Mexico (Randall, 1962) to Australia (Woolmington, 1958), Indonesia (Wertheim, 1959) to Nyasaland (Van Velsen, 1960) to name just a few studies undertaken at the time. Demography and economics were among the fields that retained a firm interest in the relation between migration and development, but in most disciplines neo-classical theories of economic growth and the benefits of development were on the whole not questioned. Thus Laura Randall (1962) writing about the extent to which Mexican migrants who came to the US on temporary work permits contributed to the Mexican economy suggested that 'One of the major benefits of this system to Mexico is the industrial training and education acquired, which can then be used in the Mexican economy' (p. 77). And the stream of interest on migration and development gathered pace through the 1970s and 1980 s as migration and development came to be influenced by Marxist thinking. 
The 'rediscovery' of the relation between international migration and development in recent years has been fostered through several events. First is the limited success of much development practice thus far and the hope that migrants may be able to overturn current developmental failures and foster development. In the post World War 2 era the world has seen limited success in the development machinery's attempt to secure development. Although development has itself metamorphosed as a concept from economic growth (Rostow, 1964) to, basic needs (Moser, 1993), poverty reduction or sustainable livelihoods (United Nations, 1987), very little comprehensive success can be claimed by the development industry. Thus, all these development paradigms have come and gone but inequality and poverty remain a haunting presence in a globalising world. However, increasing consciousness of the role that migrants play in redistributing wealth has meant that migrants have come to be recognised as the latest agents of development. The Global Development Finance report of 2003 (World Bank, 2003) reported on the value of remittances for the first time and their finding that the transfer of finances achieved through remittances exceeded that through foreign aid did much to focus world attention on remittances as a driver of development. The economic potential of migrants has thus moved on to the development agenda with renewed force (Martin 2004). Migrants are also seen as direct bearers of developmental objectives, reaching places to which other development machinery has little access. And migrants' contributions to development are seen as less mediated - democratising development. This has unleashed large amounts of energy and a political desire by a variety of actors including states, development institutions and non-governmental organisations to harness migrants to the development project in explicit ways.

As second important reason for the link between migration and development is increasing concerns over migration in a securitising world. Events such as those of $9 / 11$ and $7 / 7$ too have come to be read as one of the ways in which poverty and a sense of injustice extraterritorially developed could effectively come 'home' to the Global North ${ }^{2}$ and be vividly and tragically displayed (see Watts, 2003 for instance; Duffield, 2006). Lack of development in the South thus gets written into the Northern political agenda as the insecurities for nonmigrants. This fear of migration has resulted in unending searches for ways to restrict migration and development at home has come to be recognised as one possible route to limiting migration (see de Haas, 2006a for a discussion). The European Union, for instance, has a-

\footnotetext{
${ }^{2}$ Securitisation of migration takes different form in different places. In particular 'South-South' migration may have a range of different vectors and orthagonal articulations that shape it.
} 
dopted aid packages for those who help to secure its hallowed territories from the incursion of migrants (Bhagwati, 2003).

Public and political anxieties about migration from the Southern ${ }^{3}$ countries to the North have been heightened in the past few years with the rise of anti-immigration lobbies and political parties. With recognition that the rising forms of migration are indeed those over which the governments of Northern countries have little control has led to attempts by some governments to recuperate a narrative of control through the institution of 'managed migration policies' (Widgren and Martin, 2002; see for example, The Home Office, 2005). These inherently aim to restrict migration but also to select the most 'deserving migrants'. It is no surprise that around the same time migration from the South also came to be wrapped up as a developmental loss to these countries. Restricting migration then came to be seen as an ethical developmental choice by Northern countries (Martin, 2004).

It is important to recognise that these are some of the scenarios within which the link between 'migration and development' is being discussed. The outcomes of those discussions are often varied but reflect some aspects of these concerns as I explore in the next section.

\section{Migration and development - causalities}

At a meta-level of analysis almost all theorisations of the link between migration and development assume migration to be something that can be contained, regulated or influenced, development as normatively good. However the direction of causality between migration and development and hence the measure with which to interfere within these relationships to improve developmental outcomes remain open to multiple interpretations (de Haan, 2006). One argument suggests that underdevelopment is a 'route cause for migration'. This view has spurred a whole range of policy initiatives (see Gent, 2002 for a critique). It has led to insistent linking between trade and migration - a linking that is covered in a vast literature (Faini et al. 1994). Thus, Widgren and Martin (2002) for instance, explore whether migration would be most effectively reduced in a free trade environment or one with restrictions. Various policy instruments have also been developed to make the linkages between develop-

\footnotetext{
${ }^{3}$ The terms 'developed' and 'developing', 'First' and 'Third Worlds', and 'Global North' and 'South' are imbued in political and ethical issues about their suitability. However, in this paper I do not enter these debates but see McFarlane, 2006a for an interesting discussion.
} 
ment aid and migration 'effective'. Instrumentalist policies use aid to encourage return under a range of guises. One example is the codevelopment policies adopted by the French government whereby Malian and Senegalese migrants were encouraged to return to their countries and were given financial packages to establish businesses etc. on their return.4 Moreover, efforts to stop migration may also become a conditionality in aid packages. The disciplining effect of aid on migration is muted in some countries' development thinking. For instance, some governments, most notably Scandinavian governments have resisted the attempt to make these links explicitly embedding their development policies firmly within universalist principles of equality (CESPI, 2003)5. Whether linking migration to aid or trade the normative assumption at a meta-level of analysis is however usually that migrants' mobility must be contained.

In the above analysis migration is seen as an effect of underdevelopment. However, the opposite viewpoint has also been postulated. Thus for some theorists it is not underdevelopment that is the cause of migration but rather development that inevitably leads to migration. Using a historical analysis of migration in the context of the development of the nation -state in Europe, they argue that migration may be one off-shoot of development and that every state goes through a period of migration on its path to development - unattractively called the migration hump (Martin, 1993). National trajectories are transposed onto the individual migrant to show how it is not the very poorest who migrate but that a degree of social and economic well-being is necessary for migration to occur. In this story migration is inevitable, although not necessary laudable. In a further sophistication of this analysis it is argued that the many countries who are in a similar state occupy a 'migration band' (Olesen, 2002). In a linear trajectory of development, this period is historically limited and will be replaced by a period of in-migration as countries achieve developmental maturity. Migration is better tolerated in this scenario as it is considered an inevitable, usually reversible result of development.

Pro-mobility researchers too find the link between migration and development troubling (Sriskandarajah, 2005). Thus, for critical development researchers migrants have become key players in redistributive activities globally. They have been identified as the purveyors of our professed need/desire for equity and justice. Their bodies bear critical migration theorists'

\footnotetext{
${ }^{4}$ Although the success of such ventures appears to be limited, according to the World Bank, either through a lack of entrepreneurial skill amongst those who establish such businesses or due to a poor environment for investment (Global Economic Prospects, 2006, Chapter 3).

${ }^{5}$ However, these policies may also be shaped by the fact that the total numbers of migrants to Scandinavia is relatively small.
} 
global sense of responsibility for addressing issues of poverty. And this concern has spurred a vast body of literature on the migration development nexus with particular organisations, policy makers and NGOs claiming specialist interest in the contours of this relationship. 'Migration and development' is a new part that we can bolt on to the development machinery.

\section{Key concerns}

Migration and development policies focus on a constellation of packages which broadly aim to limit the costs of mobility to the sending nation enhance the benefits of mobility and those that offer a more complex recognition of costs and benefits of mobility but still imagine a role for development institutions and migration policy makers in their better management. The first is on the whole mobility unfriendly while the latter two are more tolerant of migration and mobility - even occasionally mobility friendly? They also centre on an imaginary of migrants as vehicles for the movement of capital, goods, social mores, 'knowledge', political leanings and cultural practices. And so national governments (see for instance, Ministry of External Affairs, 2001), international funding organisations (OECD, 2005) and diasporic organisations (de Haas 2006b) have all mobilised migrants to fund development initiatives in the countries of origin ${ }^{6}$.

The most lauded contribution of migrants to development has been the remittances they send home ${ }^{7}$. In fact, it is the lodestar around which the migration-development industry is congregating. In 2003 Ratha showed that the value of remittances had doubled in the past decade with a significant proportion of the money accruing to developing countries. In 2005 it was estimated that the value of remittances was USD 167 billion up from 160 billion in 2004 (World Bank, 2006: 85) although the extent of use of informal channels, remittance of social goods and under-reporting means that this figure is definitely a significant undercount8. It is

\footnotetext{
${ }^{6}$ Countries of origin, like other terms such as source countries or sending countries fail to capture the fluidity of movement, the importance of transit and the fact that countries are almost always simultaneously positioned as both sending and receiving countries, albeit for different groups of migrants. The terminologies also overplay the nation as the most appropriate unit through which the dynamics and directions of mobility are captured. However, I use the term country of origin for lack of a better phrase.

${ }^{7}$ Remittances may be considered as both subject to and subject of capital

8 These figures are marred by nomenclatural difficulties. For instance it is not clear whether institutional remittances (by governmental, inter-governmental and NGOs) should be added to remittance calculations. Whether and how to count any compensation for overseas employees which is provided within country of origin is an increasingly important issue when short-term movements and different forms of compensation have become widespread. Whether remittances should be counted on the basis of residence (irrespective of period of stay abroad)
} 
estimated that the actual value of remittances may be half as much again. As the most quantifiable of the impacts of migration on development, and also most closely tied to the resurgent economy as growth perspective (Maxwell, 2005), remittances have become a huge object of academic research (de Haas, 2005a and b) and policy discussions (World Bank, 2006). The uses of remittances in addressing inequalities and or poverty within households (see for instance, Ramirez et al., 2005), localities and for nations (World Bank, 2006) have all been debated. In particular, it is noted that remittances increase when there are disasters at the time when other forms of investment such as Foreign Direct Investment drop (Adams, 2006). Moreover, the chimeral quality of remittances, acting as breakers in poverty for low income households but as drivers of growth during better times means that it in effect is economically sensitive to be able to fill in for both (either) Foreign Direct Investments and aid. Moreover, there is an increasing engagement with the intersection between gender, generation and remittances (Ramirez et al., 2005). Goldring (2004) for instance, differentiates between collective remittances, family remittances and entrepreneurial remittances arguing that their modes of transfer, key actors, and possible impacts will all vary. The migrant is then received as the heroic figure who finds a route out of these troubled times. However, the meta-level of normative immobility for some still continues to be the ground on which this discourse operates. Remittances are a stop-gap measure, even a final measure, through which differences can be eradicated and migration reduced. Critical voices however claim that the sum of remittances from the South to the North is negative. The migration of skilled people in particular leads to a withdrawal of resources from the poorest countries (Khadria, 1999; Tanner, 2005).

This theme is particularly elaborated in a second major axis around which debates on migration and development hinge - brain drain. In fact along with remittances, this occupies most of the landscape on migration and development (see for instance, Özden and Schiff, 2006). Since the 1960s skilled migration has, at least partially, been understood through the lens of brain drain (Bhagwati, 1976; Committee on the International Migration of Talent, 1970). The notion of brain drain captures the concerns over the magnetic effects of well-funded, wellpaid scientific working environments in the U.S. and more recently Western Europe on scientists and doctors in the rest of the world, particularly countries from the Global South and Eastern Europe. The impacts of these movements were measured as gains and losses within the context of the nation state (Mejía, 1979) as brain drain for some was perceived to 
be countered by brain gain for others. However the mode of incorporation of such highly skilled professionals and the inadequate and inappropriate recognition of their skills have also produced tales of the loss of human capital due to the lack of recognition and utilisation of skills, for both the individual and the destination and origin countries; in short of 'brain waste'.

The benefits of skilled emigration to origin countries include incentivisation for education and return flows of knowledge while the negative effects of loss of skilled human-power (usually called man-power because of the supposition that brain drain is largely a male phenomena) to the knowledge, services and industries in the sending country (Bach, 2006; Docquier and Rapoport, 2004; Stark, 2004). Organisations that appear to be value-free with regard to migration may because of their pro-development agenda seek to limit the mobility of the skilled.

There have also been new and interesting linkages between migration and development in recent years. The possibilities offered by migrants to foster the scientific knowledge in developing countries, first activated in the 1970s under the UNESCO'S TOKTEN programmes have been revamped and dispersed in a whole range of initiatives around diaspora and development (AFFORD, 2000). As Newland (2004) comments this subject has been difficult to quantify although attempts are increasingly being made to produce complex econometric analyses to understand how diaspora comes together with development. However, this is an area where more sophisticated cultural and social analyses have occurred. Thus, Prema Kurien's detailed study of three villages in Kerala (2002) - a Muslim village in Mallapuram district, a Hindu village in north Thiruvananthapuram district and a Christian village in southcentral Kerala - suggests that for Muslims, emigration to the Gulf has led to a heightened awareness of their linkages with Muslim cultures elsewhere and thus encouraged them to distinguish themselves from other groups in Kerala. The lower caste Hindu Ezhava migrants were able to utilise the economic benefits of migration to challenge their caste status while the Syrian Christians who have a higher educational profile and are connected to missionary groups in other countries were able to utilise the migration experience to enhance these networks and to maximise the benefits of migration. A wide range of issues and sectors such as health (Ray et al., 2006; Stillwell et al., 2005), education (special issue of Globalisation, Societies and Education, 2006; Voigt-Graf, 2003) and environment (special issue of Ecological Economics, 2006) that have all been influenced by migration have also come to be studied.

This is a brief and potted outline of some of the dominant perspectives surrounding migration and development but as anyone can see it is a busy field with many players, forums and political positions. One reason to stand back from the buzz of activity that occurs at this particularly fertile nexus is that there are no simple principles either on mobility or development that can be used to organise one's thoughts, practices or actions. While there is broad 
agreement on the need for development, the forms of development being sought are not adequately interrogated. Rather models of development have been implicitly adopted and the spatial and temporal registers of certain versions of development unquestioningly applied. The objectives of development too seem to be fairly unproblematic. Secondly, the relationship between migration and development are also far from clear. Even in versions of development as growth, a comprehensive and persuasive argument may be developed both for and against mobility. Thus there are compelling accounts of why migration is a driver of development as well as equally persuasive arguments as to why it is detrimental to development. This partly depends on who is migrating, where they are moving from and to, how they move, what they do after they move and the political, economic, social and cultural contexts in which the movement occurs. Context is clearly critical in analysing the whole migrationdevelopment nexus. Yet legislators appear to be poised to make generalisations, to draw conclusions and to shape future migrations as well as development. Thirdly, the subject of migration is the migrant because it is the mobility of the migrant that generates the whole field of study, policies to sometimes limit and sometimes ease migration. Yet there seems to be much less interest in the migrant's own development.

This therefore seems an opportune moment to stand back and explore how the field has been configured and some common problems/issues that influence much of the field.9 In this paper I want to explore the different spatialities and temporalities in which both migration and development are played out in order to interrogate and unsettle the emerging edifice that links these two themes. Substantively the rest of the paper argues that most of the migration and development literature attempts to unsettle what I have laid out above as the paradigmatic positions around development and migration. For instance, all these approaches require envisioning migrant destination countries as spaces of acquisition and countries of origin as spaces deserving redistribution, primarily of economic wealth. It also places migrants as agents of such redistributive processes. These commonalities unite most migration research but they also inherently posit migration and development within particular spatiotemporal frames.

It is important to lay out some caveats to my arguments. My analysis focuses on what I see as hegemonic readings of the migration-development nexus. The conceptualisations on which I focus are visible in many development journals, migration journals as well as in a

\footnotetext{
${ }^{9}$ Arjan de Haan (2006) develops some similar critiques and suggests that interdisiplinarity may be one way in which to strengthen the literature on migration and development.
} 
large amount of grey material: conference proceedings, occasional papers and working papers. Together they position various organisations such as the ILO, the UN and its various organisations, $\mathrm{WHO}$, etc. as stakeholders in what is increasingly becoming a 'developmentmigration machinery' (Escobar, 1995). However, these conceptualisations are also challenged in other literatures, most notably feminist and anthropological literatures around migration (see for instance, Piper forthcoming; Osella and Gardner, 2003).

Moreover, individual authors may themselves slip between various positions with respect to knowledge. Mohan and Wilson (2005) in an essay on the impasse between the developmentalists and poststructural critiques of development (Gibson-Graham, 2003) urge us to locate our work in narratives of critical modernity. In their discussion of the divide between development studies and theory they suggest that there are at least three positions that may be adopted with regard to development studies and theory. The first involves those who produce technical knowledges about development, often drawing on mono-disciplinary oriented notions of human as homo- oeconomicus. A bridging position would involve 'two-way negotiations, with a strategic analysis of the existing political terrain, rather than asking how the terrain got to be there in the first place or whether we want to change it.' (Mohan and Wilson, 2005: 265). A third position is the radical critical version that wants to reflect the mirror back at development and check how it came to be here. Most of the migration and development literature cited above (and to which I address my critique) is produced in a developmental tradition, loosely linked to the first position. However, this is not to say that at least some of the work broadly located within the second position may also share some (but not all) of the characteristics I outline below.

In trying to unravel the terrain of migration and development one fruitful methodology is offered in the writings of Foucault. Drawing on Foucault's later work Duffield (2006) argues that international development is a form of governmentality. He suggests that the ability of the society to protect life is a key characteristic of a developmental notion of society. But it is also a modality through which power can be exercised. This ability underwent significant changes at the time of decolonisation, shifting from a biological to a socio-cultural register. For instance, security and protection is often rewritten in a socio-economic idiom in a developmental literature. Different kinds of spaces are produced through governmentality - a state space which protects life and looks after the welfare of those who have been assigned within state boundaries and a form of international biopower that regulates the transitions between states. For Dean (1999) 'this international biopolitics is a condition of the assignment of population to states and thus of social government of any form (p.100). Producing the different spaces of biopolitics requires distinct forms of rationality and knowledge - a range of visibili- 
ties, epistemes and identities (Legg, 2005). Unravelling the modalities around which the discourses of migration and development are being produced, or how we are framing our thinking about migration and development is therefore necessary to unsettle the debates and make their grounds less normative.

\section{Which migration}

\section{Calculative processes}

In recent years one of the key characteristics of the migration-development nexus is increasing calculations of this nexus (Callon and Law, 2005). A range of surveying institutions, econometric calculations and analytical methods has been deployed to count and make visible the relationship between migration and development. IMF reports, World Development reports, OECD reports, national statistics, regional government statistics, banks, infrastructural organisations, volunteering councils etc. have all been established to police and mark up the benefits and pitfalls of migration-development. The increasing technologies of knowledge around migration and development are usually thought of in terms of knowledge over ignorance but also that knowledge makes possible better governance over the nexus. Towards this there have been attempts to normalize certain knowledges, i.e. to ensure that they become normative as knowledge10 (McFarlane, 2006a and b). In counting up the effects of migration-development certain forms of migration and/development are normatively privileged certain accountabilities promulgated through their hypervisibility, others shepherded into the normative through their measurement and regulation, still others occluded through their invisibilisation. The whole industry that has developed around formal remittances and bank transfers may be taken as an example of the first. Attempts at regulating transfers, limiting hawala remittances, tracking money transferred through informal channels both through the securitisation debates and through expanded systems of governance may be seen as an example of the second. E-transfers, insta-remit facilities etc. aim to limit 'hawala'11 and increase formal remittances but these don't neglect the existence of such informal channels, rather they attempt to control it. On the other hand, certain forms of migration are treated as outside the remit or normative assumptions of migration/development. For instance, Agustin

\footnotetext{
${ }^{10}$ For Foucault these technologies of knowledge might be better thought of as forms of multiplicity (2003: 180).

${ }^{11}$ Hawala is a form of informal remittance adopted in South Asia.
} 
(2006) in her reflections on the treatment of sex workers in the migration literature argues that women migrants who sell sex are permanently placed between the dichotomy of perpetrator or victim. Frameworks of analysis such as that around migration and development are rarely applied to sex workers.

Equally significant is the invisibility of migration of development workers, researchers and policy workers which is so central to keeping developmentalism in circulation. The migration of development officials who act as agents of modernisation is never brought into the rubric of migration-development. Migration becomes a tool that maintains and keeps in circulation universalised claims of certain knowledges. Importantly that universality is essential to maintaining the teleology of development, as the power of certain kinds of knowledge about what constitutes development must be continuously secured through the embodied knowledge practices of migration professionals. For instance, Kothari's (2006) analysis of the practices through which development came to be played out through colonialism and postcolonial periods shows us that the mobility of development officials was a necessary part of developmentalism. Moreover, when one embeds this developmentalism within its wider discourse fields one can see that migration of all kinds of other individuals is necessary for developmentality. Kapur (2004) offers an insightful analysis of the ideational effects of mobility - how migrants imbibed modernist notions of universal rights and of nationhood through travelling to metropolitan centres at the end of the nineteenth and early twentieth centuries and how this shaped nationalist movements in the colonies (also see Goswami, 2005). This ideational effect can lead to development in countries of origin but it is also necessary for producing the authority of the ideas12 (and for such developmental ideas as a form of social capital, see Levitt, 1998). Thus when migrants pass back information to the new countries and so developmentalism seeps through it is also an act of power for developmentalism - the circulation of migrants keeps notions of development in motion. It is not only material practices that are ideational effects but rather ideation is a necessity for developmentalism or what we could call the power of development. Moreover, mobility can also produce developmental stories. Thus, Nancy Cook (2007) has pointed out how Northern women employed by international aid agencies to do development work in Gilgit use their mobility embodied through international travels to narrate their developed status in comparison to the women in Gilgit who are posited as underdeveloped due to constrains on their spatial mobility. Hence mobility scripts

\footnotetext{
${ }^{12}$ It is not simply transference of information as information is always transformed, appropriated and reshaped through travel (see Iskander, 2005 for an interesting discussion).
} 
the development of the 'development worker' as much as the development of those whom they are purported to 'help develop' through subjectification of the self. They point to the comportment, behaviour and qualities that help to define development and in so doing the 'operative rationales that animate aspirations aimed at shaping the conduct of others' (Osborne and Rose, 1999: 738). Thus, mobility is a strategisation of power that reinforces certain versions of development.

\section{Individual migrants, collective development}

The emerging migration/development nexus is also redolent with mechanisms through which knowledge of migration/development is being hierarchized and centralised. Dominant forms of knowledge about migration-development privilege certain sources of information and sites of knowledge-making so that (as in my earlier example) organisations such as the IMF and World Bank become the purveyors and constituting spaces for normative notions of migration/development. Their own technical knowledges are accreted through calculative processes that are promulgated through states (returns by national governments), banks and so on. Bringing together these knowledges acts to position these organisations as active producers/agents of knowledge about the nexus but also constitutes their own legitimacy in shaping the language of development (see also Foucault, 2003: 280).

For Foucault (2003) this form of visibilisation and calculation is central to the shift from sovereignty to biopolitics, from concerns over the individual to the population. Foucault remarks that at the end of the seventeenth and early eighteenth century the rapid growth in population and processes of industrialisation meant that the disciplinary mechanisms over individualised bodies were supplemented by regulations.

From the eighteenth century onward (or at least the end of the eighteenth century onward) we have, then, two technologies of power which were established at different times and which were superimposed. One technique is disciplinary; it centres on the body, produces individualizing effects, and manipulates the body as a source of forces that have to be rendered both useful and docile. And we also have a second technology which is centred not upon the body but upon life: a technology which brings together the mass effects characteristic of a population, which tries to control the series of random events that can occur in a living mass, a technology which tries to predict the probability of those events (by modifying it, if necessary), or at least to compensate for their effects. This is a technology which aims to establish a sort of homeostasis, not by training individuals, but by achieving an overall equilibrium that protects the security of the whole from internal dangers. So, a technology of drilling, as opposed to, a technology of security: a disciplinary technology, as distinct from a reassuring or regulatory technology. Both technologies are obviously technologies of the body but one is a technology in which the body is individualized as an organism endowed with capacities, while the other is a technology in which bodies are replaced by general biological processes. (249) 
These two mechanisms do not operate at the same level but rather can be articulated. And this articulation is central to the relation between migration and development. The subject of neoliberal governmentality is for Foucault (2007, forthcoming cited in Noxolo, forthcoming) a rational subject who is capable of making decisions to maximise their capital and to dispose of it in a rational manner. But they are also mobile subjects as the ability to choose whether to travel or not is an inherent part of the neoliberal subject. Moreover as Noxolo argues the 'invisible hand' of economic processes means that governments have neither the capacity nor the desire to restrict homo œconomicus's freedom to make rational economic choices'. As stated earlier the circulation of developmentality itself depends on mobile individuals.

However, this freedom afforded to the subject is double-edged. In order to bring them into the rationalities of neoliberalism and to circulate that neoliberalism it is also necessary for these freedoms to be managed and one mode of management is through the creation of a moral sentiment. As Rose (1999: 78) suggests technologies of government 'seek to instil techniques whereby selves would simultaneously practice upon themselves as free individuals and bind them into a civilized polity by means of that freedom and the modes in which it is enacted.' The migration-development nexus depends on and therefore fosters the moral sentiment that is a sense of commitment to a collective group - those who can be developed elsewhere. This sense of responsibility to a community is activated through the migrants' bodies. 'The new citizen-subject is thus constituted as an assemblage of morality and economic rationality who acts in socially appropriate ways, not because of force or coercion but, because their choices align with their "community interests" (Ilcan et al., 2007: 80). For Duffield (2006) these responsibilities are played out through a range of informal networks, families and communities which are seen as the insurance mechanisms for a population that is in many ways uninsurable. The mobile governable subject of migration/development is in this reading both required to move in order to strategise their human capital but also to act morally for the collective good of a distant place/community.

There are many problems with this version of development - the most frequently cited is that of the local effects of development, which are decidedly uneven (see for instance, Kurien, 2002 for a detailed ethnographic analysis). Communities are produced from up above as units of cohesion or common interest, denying the struggles over community and the dissonances that can be caused by uneven development (Walton-Roberts, 2001). Second, this is the version of migrant subjectivity which I referred to earlier as having to carry the responsibility for our sense of good or desire for redistribution. Migrants make the sacrifices necessary to ameliorate the effects of years of development disasters. And it is a sacrifice because 
what is unfortunately missing from this formulation is any sense of individual betterment and purposive development that is not caught up in redistribution.

Sarti (2006) in a thoroughgoing analysis of the role of domestic work in European identities discusses the ways in which domestic work was seen as a route to self-improvement, an educational technology in the eighteenth and nineteenth centuries in Europe. She locates Broom and Smith's (1963) analysis of domestic work as a bridging occupation within the European context arguing that this educational imperative has however increasingly disappeared amongst migrant domestic workers of today. Her example provides a useful example of how work became a tool through which people could be governed to invest in their own capital and how the household now becomes one site for governing populations. Sarti focuses on the characteristics of domestic work but we could note that domestic workers were also often migrants, often working class, often rural for whom migration offered an accelerated entry to modernity. The ability to develop oneself through mobility was an important tenet of migration, especially but not in literatures on internal migration. However, only elements of these are being recuperated and exteriorised in the new initiatives around migration and development. Thus, self-development through migration is limited to those who move with an already available composite of skills13. But there is much of value in the older literature which shows how personal development, social mores and opportunities to 'jump class' were part of what migration could enable for the migrant. A focus on territorial redistribution of the benefits and potentials of migration is however often achieved by migrants' selfregulation of their own access to such forms of capital. Remittances sent for instance are also about money that is no longer available to individual migrants to secure their own wellbeing or indeed access to further education. It is through the travails and the sacrifices of Gulf migrants from Kerala, India who share tiny accommodation with myriad others in order to send money home that our development dreams are played out. Moreover, in continuously forging and maintaining links with distant others few resources are available to secure the social friendships and connections with proximate others. Bridget Anderson (2000) in her study of Indian domestic workers in the UK interviewed a woman who had for long sent money home but as she becomes older and her place-based connections with Indians in India become diluted through distance, her lack of social networks, the absence of friends

\footnotetext{
13 In fact much of this discussion is (problematically) limited to student migration. However, students who can afford to migrate internationally are often already bearers of social capital and class distinctions. Skilled labour migrants often appear to come pre-packaged with a set of resources and human capital that is simply deployed in different settings (Raghuram, forthcoming - c).
} 
locally who might care for her in her old age become pressing (personal communication). This is the price of fostering particular versions of migration and development that deny the insistent everyday nature of wellbeing as well as the longer-term needs of migrants everywhere.

\section{What development}

\section{Developmentalism as modernity}

Most of the literature I cite in the first section seems to be firmly located in a version of developmentalism. Dirlik (2003) argues that this 'is not just a positive evaluation of development but a commitment to development as a principle of survival, so that not to develop becomes equivalent to social and political death. Modernity as colonialism is most readily visible in the universalization of the ideology of development when all other universalisms are seemingly in doubt.' (2003: 433). Developmentalism is clearly located in a universalising version of modernity and its particular teleologies.14 There are few spaces for discussion of resistance to 'development initiatives' or to have modes of autonomy that are not related to dominant modernities.15 Development is preconfigured so that activities outside this norm come to be presented as 'anti-developmental'. Alternatives to development and even alternative forms of development become marked through struggle with this normalizing discourse. At best such alternatives may be met with incomprehension. Page (forthcoming) in his study of hometown associations' role in development in Cameroon presents an example where the first item of expenditure that the diaspora considered in their developmental expenditure was the construction of a mortuary. Funding funeral services too formed a large part of what the diasporics identified as their most pressing developmental need. These are the visions of development that do not get included in wider discussions of migration and development. The considerable amounts of research and thinking that explore the relationship between migration and alternative modernities (Goankar, 1999; Spivak, 2002) too are not usually folded into the debates on migration and development.

\footnotetext{
${ }^{14}$ Thus we see little scope for political alternatives for imagining development (although social and cultural ones that are normatively defined within notions of universalising moral responsibility may well be accommodated.

${ }^{15}$ The definition of dominant may however vary contextually. They also vary over time (Thorbecke, 2006).
} 
In locating development unreflexively within the frameworks of modernity we also borrow its particular time orientation, especially a foreshortening of the time that we focus on (Jones, 2004). We often adopt a 'time conception looking forward to this worldly future, open, novel, reachable or constructable, a conception seeing the present as a possible preparation for a future, and the past either as something to leave behind or as a heap of ruins, pieces of which might be used for building a new future (Therborn, 2003: 294). In development this 'temporalizing of difference' (Helliwell and Hindess, 2005: 414) whereby some people and some places are always seen as caught in the past is particularly acute. Both the relationality of the temporal frame (developed/modern - underdeveloped/traditional) and the desire to transform from one temporal register to another are central to the construction of development. The concept of relative deprivation carries within it this teleology - not only difference but also a directionality of how change should occur to erase this difference. Such temporalities are thus implicit in analyses that posit migration in relative deprivation16 (Skeldon, 2002; de Haas, 2006a).

Many different temporal structures and textures of time are however often missed. For instance, dominant stories of brain drain of medical migrants effectively erase a number of other narratives and the different qualities of time in which they are embedded. It forgets that medical migration is configured by a range of other practices with longer histories. Thus the migration of doctors from India to the UK (Mensah et al., 2005) has to be placed not only within the context of differences in wages and working conditions but also in the subalternisation of local medical practices during colonial periods (Forbes, 1994); the adoption of the language of science by those in the class-caste hierarchy who led independence movements (Kamat, Mir and Matthew, 2003) and their effective transposition to arbiters of modernity in decolonising nations (Prakash, 1999); and the practices of imperial institutional hierarchies such as Royal Colleges in medical practice that still hold sway in defining medical knowledge (Aluwihare, 2002) and as international credentialing organisations (but see for instance, Raghuram, forthcoming - a). Through adopting a genealogical approach that keeps in mind the complex matrix of rationalities and subjectifications that produce the subject of brain drain we can take account of some of these different temporalities and hence narrate a different story of brain drain. History, in this instance, does not define us but it produces some relations through which we construct ourselves. Similarly brain drain is not simply a product of colonial affiliations or postcolonial reconfigurations but these analytical tools do provide us

\footnotetext{
16 This form of poverty reduction is linked to but not contained by terms such as poverty reduction.
} 
with some forms of attachment and certain forms of path dependency through which we can understand medical mobility. These methods can be applied not only to understand certain forms of migration but also to recognise the histories of notions of development as enacted and practiced through its institutional and policy matrix. The importance of historical conditions in shaping both development practices and institutions cannot be underestimated (Chang, 2003, cited in Maxwell, 2005).

\section{Development as spatilaised power}

Development not only has particular temporal qualities but also adopts distinctive spatial registers. Specifically, many discussions of migration and development aim to

cohere particular spatialities, to invoke a moral responsibility to care for particular locations and thus to territorially fix moral responsibility of migrants, to reinforce the state and as a prefigured entity, and to do these by operating a particular form of here-there binary logic to our spatial understandings of migration-development - issues to which I turn below.

As we have seen in the earlier section migrants are invited to participate in development when they can affirm the legitimacy of the discourse of development - both the nature of its problem identification and its search for corresponding solutions. Migrants must reinforce the normative assumptions about the teleology of development if they are to be folded into hegemonic discourses of migration-development. They thus become both the subjects of migration and subject to migration-development policies. And those who do not subscribe to it are invisibilised in the official discourses of migration-development. Importantly, this also locates migrants with particular forms of spatial affiliations. Thus we do not consider the contributions of individual migrants whose offerings may not be easily aligned with an imaginary conception of the needs of a community or a wider group as developmental. Even less likely to be included in the framework is the development efforts of those who are seen as disrupting such communities, influencing the spatial imaginaries of the groups.17 Thus, the use of remittances to fund 'independence' movements is rarely seen as a developmental act as

\footnotetext{
${ }^{17}$ Equally one could question the normativity of social networks as socially desirable tools in development. The same tool very quickly becomes cast as clientistic structures or corrupt processes when the teleologies of development are challenged. In practice we may also wonder whether diaspora development programmes are therefore faulty because they identify strong leaders who can forge development in certain territories but can escape accountable mechanisms within those territories through their locatedness elsewhere. Should migrants who fall outside local accountability mechanisms be allowed to unduly influence development?
} 
developmentalism aims to reinforce social economic and political processes within statuted spatialities. Yet when these movements are successful the very same processes are narrated as developmental in a post-hoc rationalisation of the same practices that were earlier threatening and anti-developmental. Normative spatial settings, thus, have a powerful influence on how and when migrants' activities become marked as developmental.

Second, as argued earlier we see an individuation of the moral responsibility to care for the other but these others are territorially located in particular lands. Migrants are asked to enact particular attachments and perform a form of localised responsibility to specific locations and groups. Thus brain drain migrants are viewed entirely through their spatial dislocation from a normative requirement to care for co-nationals. Thus doctors and scientists if they go abroad at all must return to provide services to their own countries (Black and Gent, 2004). As a result incentive schemes such as increases in salary and additional allowances pension schemes, insurance schemes, clothing allowance, travel allowance, child care allowance, subsidised meals and accommodation, and training are all being considered as part of an ethical policy to addressing brain drain (Crisp, 2007; Kupfer et al., 2004). What is clear is that the locale of a migrant's 'development activities' must necessarily be their home territories.

Third, development is often counted in particular sites and in particular forms so that there is a privileging of the state as the arbiter of development practice. In academic and policy discussions on migration and development we see a return to modernisation paradigms of development and to its scalar emphases on the nation. There is a re-emergence of a new meta-narrative of development which is replacing the Washington Consensus (Maxwell, 2005). This new and improved orthodoxy 'emphasises the Millennium Development Goals (MDGs) as an over-arching framework, and lays out the link between the MDGs, nationally owned poverty reduction strategies, macro-economic policy (including trade), effective public expenditure management, and harmonised aid in support of good governance and good policies (Maxwell, 2005:). These are often strategized, brokered and measured at national scales. Once again we see versions of development garnering and reinforcing state power over populations.

Significantly, development is also embedded in a certain kind of verticalism (Ferguson and Gupta, 2002). A large number of studies do recognise the developmental effects of migration on households, villages and communities but they always occur in a nested formation, a verticalism. In the large literature on social networks, migration, diaspora and development are 
often underlain by the normative notion of how such networks can become instruments for verticalised control18. For instance, the way in which this question is framed is often 'How can social networks deliver the aims and objectives of developmental states/institutions?'

Drawing on Iskander (2005) we can argue that the state is operationalised here as distinctive from society or rather that state practices operate to distinguish themselves from the social practices through which they are constituted. 'As a separate and autonomous institution, the state acts on social dynamics: it directs transfers, it facilitates exchange of property, it controls or enables the movement of people. In that endeavour, the state may act on the most intimate aspects of people's lives, and may intervene to affect minutia of everyday exchanges to achieve a policy goal. Ultimately, however, in this representation of the state, its actions always remain analytically and materially distinct from the dynamics it seeks to manage (p. 13).' Thus it may solicit the contributions of migrants, such as NGOs, for instance, but it is not viewed as a set of practices which are inherently part of society.

The state is not only held together as coherent through such manoeuvres but also seen as stationary in its relationship to both migration and development. In practice, moreover, the scripts of migration and development are usually being co-written alongside those of the nation-state. Thus, as the nature and aspirations of nation-states alter they emphasise different aspects of the migration-development nexus. Shifts in the imaginaries of nation and its territoriality, and the politics of the relationship between the two also influence how the impacts of extra-territorial populations on the nation are scripted. For instance, in narratives of loss the nation-state is often seen as a project that has to be continuously secured, sometimes through and sometimes despite its distanciation from its extra-territorial populations. Expansive definitions of affiliations to a 'mother country' are, on the other hand, adopted in narratives of migration as gain. And the definition of nation may itself be altered to accommodate the nature of engagement with the diaspora, subjugating residential location to other forms of linkages that people may have to countries from which they or their ancestors hold connection. And although the effects of migration on development are always complex and contradictory narratives of gain or loss may predominate depending on the context in which the nation is procuring its identity. For an example of how these processes of nation-building and narratives of migration and development are intercalated in the case of India, see Raghuram forthcoming - b).

\footnotetext{
${ }^{18}$ Moreover, even things like building temples at home get thrown back into the fray of cultural continuity, itself a form of national development that re-secures the nation.
} 
Finally, the migration-development nexus is wholly dependent on a spatial separation between near and far, between 'here' and 'there' which are embedded within ontological notions of Euclidean space (McFarlane, 2006b). And in this formulation migrants 'here' always help to develop territories, societies, families and individuals over 'there'. Arguably, this requires imagining development as spatial distance. 'This vision perpetuates a North-South divide: 'poor' countries are to draw on the knowledge of 'rich' countries in order to develop. (McFarlane, 2006b: 289). Migrants become the agents of such development and attempts to regulate migrants' role in development an embodied attempt to rule over distance, to regulate those who live in far away places through proximate subjects.

At the same time, the territorial fixings of migration and development literature also retain a belief in some version of stepped development. Migrants to poor countries who remit money home to their own countries are not really urged to remit in the name of development. Yet so much of the money that is brought in to develop the Northern countries has at least since colonial times come from the countries of the global South. This is a focus that early literature on migration and development recognised (see for instance, Von Sternburg, 1906; Kelley, 1965) but these sensibilities have since faded19. For instance, if we take Chakrabarty's (2000) argument about the co-constitution of Europe and the colonies seriously we can see that the flows of information, knowledge, and economic wealth (at a minimum) were critical to the development of Europe. Equally, these flows helped to produce the range of migration destinations and sending locations as the trajectories of movement of people, goods and flows criss-crossed the earth in this early phase of globalisation (and see Hatton and Williamson, 2006 for an interesting analysis). And these processes continue. We could then more fruitfully see different places as co-constituted. We would even argue that migration actually leads to development in the North. Yet when we hear about members of the Northern transnational capitalist class who live in the South establishing businesses and remitting their profits to the North we are never encouraged to think of this as development, only as transnational flows of capital.

Rather, if we adopt a topological analysis (Allen, 2003) of the links between migration and development we will recognise that the spaces for/of development are already mixed up, that

\footnotetext{
${ }^{19}$ Thus, although there is some literature on the benefits that migrants bring to the Global North, this is not easily or necessarily folded into stories of development (Coleman and Rowthorn, 2004). The migration and development literature often privileges the North-South binary in narratives of development. Some of the literature, particularly that on brain drain is also taking on an East-West perspective in recognition of the effects of the opening up of immigration from the 10 'accession countries' of Eastern Europe to some of the countries in Western Europe.
} 
migrants here might need development, migrants there may be agents of development here. In fact, it could even unsettle our ability to adopt a here-there framework20.

\section{Conclusions}

In this paper I have attempted to unpick some of the characteristics that are central to much of the writings at the particularly fertile nexus between migration and development. For instance, the narrative of development is embedded in certain versions of universalism; even local development depends on a sense of welfare or capability that is universally shared. There is little room for removing development from a version of modernity to which it is deeply tied. However, one step towards unsettling this cosy relationship between migration and development would be to look at the two as co-produced and to recognise how migration is central to constituting the paradigm of development. We should move outwards and reframe our analysis of migration and development to take on board the literature on migration that does not profess to be development and see how it can disrupt the narrative of development. The calculative processes through which the visibilisation of some migrants is achieved and the processes of development proscribed too merits investigation. For Foucault (2003: 253) 'the norm is something that can be applied to both a body one wishes to discipline and a population one wishes to regularize'. Unsettling these norms and denaturalising them can help us to see what may be occluded through our ways of thinking the nexus. It can also open up the possibility for us to visualise this nexus at multiple spatial registers and temporal scales. For instance, a historical analysis of how migration was seen as personally developmental, rather than nationally developmental can help to alert us to the personal losses that migrants who focus on development over 'there' might face. A genealogical approach can tell us much about how fragments of history shape our development thinking but equally challenges this thinking. What qualifies for calculation, or qualculation (Callon and Law, 2005) in the migration development nexus needs reimagining. 'What is important is that we make sure that qualculation does not get itself attached to a narrow understanding of space-time framing. The character of comparability, and manipulability, this needs to be left

\footnotetext{
20 This is most well achieved in the transnational analysis of migration. However, much of the literature because of its emphasis on the agency of migrants has relatively neglected a theoretical analysis of the transnationalism of migration regulations and the forms of spatialised power that they invoke. Furthermore there is still work to be done that critically links the work of development agencies with transnational migrants.
} 
open. At a guess, for instance, judgment is often distributed across time and geographical space. It flows, unfolds, and reflects local specificities. It cannot be drawn together at a single commonsense space and time' (Callon and Law, 2005: 720).

In conclusion, much migration-development literature leaves in place any substantive restructuring of social orders as it refuses to acknowledge how migration unsettles certain scalar politics and temporal frames while scaffolding others. So in producing our own work we must engage actively in disassembling the narrative and interrogating its frameworks if we are to prevent the migration development nexus from congealing into normative frames. 


\section{References:}

Adams, R. H. (2006). Migration, Remittances And Development: The Critical Nexus In The Middle East And North Africa, Paper Presented At The United Nations Expert Group Meeting On International Migration And Development In The Arab Region Population Division, Department Of Economic And Social Affairs, United Nations Secretariat, Beirut, 15-17 May 2006.

Allen, J. (2003). The lost Geographies of Power. Oxford: Blackwell.

AFFORD (2000). Globalisation and development: $A$ diaspora dimension. Submission by the African Foundation for Development (AFFORD). to Department for International Development's White Paper on Globalisation and Development, May 2000.

Agusti'n, L. (2006). The Disappearing of a Migration Category: Migrants Who Sell Sex. Journal of Ethnic and Migration Studies, 32, 29- 47

Aluwihare, A. (2002). The long arm of the RCS. The Bulletin of the Royal College of Surgeons of England, 84, 288.

Black, R., \& Gent, S. (2004). Defining, Measuring and Influencing Sustainable Return: The case of the Balkans, Working Paper T7, DRC, Brighton.

Bhagwati, J. (2003). Borders Beyond Control. Foreign Affairs, 98-104

Bhagwati, J. (1976). The Brain Drain and Taxation - Theory and Empirical analysis. Amsterdam: North-Holland Publishing Co.

Anderson, B. (2000). Doing the Dirty Work? The Global Politics of Domestic Labour. Zed: London.

Broom L., \& Smith J. H. (1963). Bridging Occupations. British Journal of Sociology, 14, 321334.

Callon, M., \& Law, J. (2005). On Qualculation, agency and otherness, Environment and Planning D: Society and Space, 23, 717-733.

CESPI (2003). "More Development For Less Migration” Or "Better Migration For More Development"? Shifting Priorities In The European Debate. available at http://www.cespi.it/bollMigraction/MigSpecial3.PDF (accessed 6 November 2006) 
Chakrabarty, D. (2000). Provincializing Europe: post-colonial thought and historical difference. Princeton, NJ: Princeton University Press.

Chang, H.J. (2003). 'Institutions and Economic Development in Historical Perspective'. In H.J Chang, (Ed). Rethinking Development Economics. London: Anthem Press

Coleman, D., \& Rowthorn, R. (2004). The Economic Effects Of Immigration Into The United Kingdom. Population and Development Review, 30, 579-624.

Committee on the International Migration of Talent. (1970). The International Migration of High-level Manpower: Its impact on the development process. Praeger Special Studies in International Economics and Development. New York: Praeger Publishers.

Cook, N. (2007) Gendered Globe-Trotting: Mapping Development Travels in Northern Pakistan, Paper presented at the Annual Association of American Geographers, April 17-21, San Francisco.

Crisp, N., (2007). Global health partnerships: The UK contribution to health in developing countries, London, DFID.

de Haan, A. (2006). Migration in the Development Studies literature: has it come out of its Marginality? UNU-Wider paper

de Haas, H. (2006a). Turning the tide? Why development instead of migration policies are bound to fail. IMI working paper 2. Oxford: International Migration Institute, University of Oxford.

de Haas, H. (2006b). Migration, Remittances and Regional Development in Southern Morocco. Geoforum, 37, 565-580.

Dirlik, A. (2003). Where do we go from here? Marxism, Modernity and Postcolonial Studies. Diaspora: A Journal of Transnational Studies, 12, 419-436.

Dean, M., (1999). Governmentality: Power and rule in modern society, London, Sage.

Docquier, F., \& Rapoport, H. (2004). Skilled migration: the perspective of developing countries, World Bank, Washington, DC.

Duffield, M. (2006). Racism, Migration and Development: the foundations of planetary order. Progress in Development Studies, 6 -12. 
Ecological Economics (2006). Special issue on migration, globalization and the environment. 59 (2).

Escobar, A. (1995). Encountering Development: The making and unmaking of the Third World. Princeton, NJ: Princeton University Press.

Faini, R., \& Venturini, A. (1994). Trade, aid and migrations. Some basic policy issues. European Economic Review, 37, 435-442.

Ferguson, J., \& Gupta, A. (2002). Spatializing states: toward an ethnography of neoliberal governmentality. American Ethnologist, 2, 981-1002.

Forbes, G. (1994). Medical careers and health care for Indian women: patterns of control. Women's History Review, 3, 515-530.

Foucault, M. (2003). Society Must be Defended. London: Penguin.

Gent, S. (2002). The Root Causes of Migration: Criticising the Approach and Finding a Way Forward, Working Paper N. 11, Sussex Centre for Migration Research, available on http://www.sussex.ac.uk/migration/publications/working papers/.

Gibson-Graham, J.K. (2003). The impatience of familiarity. Singapore Journal of Tropical Geography, 24, 35-37.

Goankar, D. (2001). On alternative modernities. In D. Goankar (Ed.), Alternative modernities, (pp. 1-18). Durham, NC: Duke University Press.

Globalisation, Societies and Education (2006). Brain drain, brain gain and brain circulation Special Issue, 4(1).

Goldring, L. (2004). Family and Collective Remittances to Mexico: A Multi-dimensional Typology. Development and Change, 35, 799-840.

Goswami, M. (2005). Autonomy and Comparability: Notes on the Anticolonial and the Postcolonial. boundary 2, 32, 199-223.

Hatton, T. and Williamson, J. (2006) What Determines Immigration's Impact? Comparing Two Global Centuries, NBER Working Paper 12414, available at: http://www.nber.org/papers/w12414 (accessed May 3, 2007) 
Helliwell C., \& Hindess B. (2002).The Empire of Uniformity and the Government of Subject Peoples. Cultural Values, 6, 139-152.

Ilcan, S., Oliver, M., \& O'Connor, D. (2007). Spaces of Governance: Gender and Public sector restructuring in Canada. Gender, Place and Culture, 14, 71-92.

Iskander, N. (2005). Innovating state practices: migration, development, and state learning in the Moroccan Souss, MIT-IPC working paper series: MIT-IPC-05-009 available at: http://web.mit.edu/ipc/publications/pdf/05-009.pdf (Accessed 10 November 2006)

Jones, R. (2004). What time Human Geography? Progress in Human Geography, 28, $287-$ 304.

Kamat, S., Mir, A., \& Mathew, B. (2003). Producing hi-tech: globalization, the state and migrant subjects. Globalisation, Societies and Education, 2, 1 - 39.

Kapur, D. (2004). Ideas and economic reform in India: the role of international migration and the Indian diaspora. India Review, 3, 364-384.

Kelley, P. (1965). International migration and economic growth, Australia: 1865-1935. Journal of Economic History, 25, 333-354.

Khadria, B. (1999). The Migration of Knowledge Workers: Second-generation effects of India's Brain Drain. Sage: New Delhi.

Kothari, U. (2006). Spatial practices and imaginaries: Experiences of colonial officers and development professionals. Singapore Journal of Tropical Geography, 27, 235 -253.

Kupfer, L., Hofman, K., Jarwan, R., McDermott, J., \& Bridbord, J. (2004). Strategies to discourage brain drain. Bulletin of the World Health Organisation, 82, 613-623.

Kurien, P. (2002). Kaleidoscopic Ethnicity: International Migration and the Reconstruction of Community Identities in India. New Jersey: Rutgers University Press.

Legg, S. (2005). Foucault's Population Geographies: Classifications, Biopolitics and Governmental Spaces. Population, Space and Place, 11, 137-156.

Levitt, P. (1998). Social Remittances: Migration Driven Local-Level Forms of Cultural Diffusion. International Migration Review, 32, 926-948.

Martin, P. (2004) 
Martin, P. (1993). Trade and Migration: NAFTA and Agriculture, Institute for International Economics, Washington, DC.

Maxwell, S. (2005). The Washington Consensus is dead! Long live the meta-narrative! Working Paper 243 http://www.odi.org.uk/publications/working papers/wp243.pdf

McFarlane, C. (2006a). Crossing borders: development, learning and the North-South divide. Third World Quarterly, 27, 1413-1437.

McFarlane, C. (2006b). Knowledge, learning and development: a post-rationalist approach. Progress in Development Studies, 6, 287-305.

Mejia, A., Pizurki, H., \& Royston, E., (1979). Physician Migration and Nurse Migration: Analysis and Policy Implications. Geneva: WHO.

Mensah., K., Mackintosh, M., \& Henry, L. (2005). The 'Skills Drain' of Health Professionals from the Developing World: A Framework for Policy Formulation. MEDACT, London. Available at:

http://www.medact.org/content/Skills\%20drain/Mensah\%20et\%20al.\%202005.pdf

Mohan, G., \& Wilson (2005) The antagonistic relevance of development studies. Progress in Development Studies, 5, 4, 1-18

Ministry of External Affairs (2001). Report of the High Level Committee on the Indian Diaspora. New Delhi: Government of India.

Moser, C. (1993). Gender planning and development Theory, practice and training. London : Routledge.

Newland, K. (2004). Beyond Remittances: The Role of Diaspora in Poverty Reduction in their Countries of Origin. Migration Policy Institute, Washington, DC.

Noxolo, P. (forthcoming). Playing the scales? NGO networking as mechanism of security in a governmentalising world, Political Geography.

Nyberg-Sørensen, N., Van Hear, N., \& Engberg-Pedersen, P. (2002). The MigrationDevelopment Nexus: Evidence and Policy Options. International Migration, 40, 49-71.

OECD (2005). Migration, remittances and development. Paris: OECD. 
Olesen, H. (2002). Migration, Return and Development: An Institutional Perspective. International Migration, 40, 125-150.

Osborne, T., \& Rose, N. (1999). Governing Cities: Notes on the Spatialisation of Virtue. Environment and Planning D: Society and Space, 17, 737-360.

Osella, F., \& Gardner, K. (2003). Migration, modernity and social transformation in South Asia. New Delhi: Sage.

Özden Ç., \& Schiff, M. (Eds). (2006). International Migration, Remittances, and the Brain Drain. World Bank, Washington, DC.

Page, B. (forthcoming). Slow going: The mortuary, modernity and the hometown association in Bali-Nyonga, Cameroon. Africa.

Piper, N. (forthcoming) New Perspectives on Gender and Migration: Livelihoods, Rights and Development.

Prakash, G. (1999). Another Reason: Science and the Imagination of Modern India. New Jersey: Princeton University Press.

Raghuram, P. (forthcoming -a). Thinking ethically about the brain drain: colonial legacies, postcolonial reconfigurations, Geoforum.

Raghuram, P. (forthcoming- b). Conceptualising Indian emigration: the development story, in Ton van Naerssen, Ernst Spaan and Annelies Zoomers (eds) Global Migration and Development.

Raghuram, P. (forthcoming- c) Governing the mobility of skills, In C. Gabrielle \& H. Pellerin (Eds.), Governing International Labour Migration, New York: Routledge.

Ramírez, C. García Domínguez, M. Míguez Morais, J. (2005). Developing a framework to understand the relationships between migration, gender, remittances and development, United Nations International Research and Training Institute for the Advancement of Women (INSTRAW).

Randall, L. (1962). Labour Migration and Mexican Economic Development. Social and Economic Studies, 11, 73-81. 
Ratha, D. (2003). 'Workers' Remittances: An Important and Stable Source of External Development Finance", In World Bank (Ed.) Global Development Finance 2003, (pp 157175) Washington, DC, World Bank.

Ray, K. M., Lowell, B. L., \& Spencer, S. (2006). International Health Worker Mobility: Causes, Consequences, and Best Practices. International Migration, 44, 181-203.

Rose, N. (1999). Powers of Freedom. Cambridge: Cambridge University Press.

Rostow, W. (1964). The Stages of Economic Growth: A Non-Communist Manifesto. London: Cambridge University Press.

Sriskandarajah, D. (2005). Migration and Development. GCIM, September available at http://www.migrationdevelopment.org/fileadmin/data/resources/general/research pap ers/Thematic Study 4 01.pdf (accessed 12 January 2007)

Stark, O. (2004). Rethinking the brain drain. World Development, 32, 15-22.

Stilwell, B., Zurn, P., Connell, J., \& Awases, M. (2005). The Migration of Health Workers: An Overview, WHO Report to the World Health Assembly, Geneva.

Sarti, R. (2006). Domestic Service and European Identity in S. Paselau and I. Schopp (eds.), with R. Sarti, Proceedings of the Servant Project, Éditions de l'Université de Liège, Liège, vol. V.

Skeldon, R. (2002). Migration and Poverty. Asia-Pacific Population Journal, 17, 67-82.

Tanner, A. (2005). Brain drain and beyond: returns and remittances of highly skilled migrants, Global Migration perspectives, No. 24. GCIM available at:

http://test.gcim.org/gmp/Global\%20Migration\%20Perspectives\%20No\%2024.pdf (accessed July 13, 2006)

The Home Office, 2005

Therborn, G. (2003). Entangled modernities. European Journal of Social Theory, 6, 293-305.

Thorbecke, E. (2006) The evolution of the development doctrine, 1950-2005. UNU-Wider United Nations (1987). Report of the World Commission on Environment and Development, Report of the Brundtland Commission. 
Voigt-Graf, C. (2003). Fijian teachers on the move: Causes, implications and policies. AsiaPacific-Viewpoint, 44, 163-175.

Von Sternburg, S. (1906). Imperial German Ambassador to the United States, German Emigration and South American Settlements. North American Review, 182, 641-650.

Van Velsen, (1960). Labor migration as a positive factor in the continuity of Tonga tribal society. Economic Development and Cultural Change, 8, 265-278.

Walton-Roberts, M. (2001). Returning, remitting, reshaping: Non-Resident Indians and the transformation of society and space in Punjab, India Working paper series, No. 01-15, RIIM, Vancouver.

Watts, M. (2003). Development and governmentality. Singapore Journal of Tropical Geography, 24, 1-35.

Widgren, J., \& Martin, P. (2002). Managing Migration: The Role of Economic Instruments. International Migration, 40, 213-229

Woolmington, E.R. (1958). Post-war immigration and industrial development in Australia, Australian quarterly, 30, 77-78.

World Bank (2006). Global Economic Prospects 2006: Economic Implications of Remittances and Migration, Washington, DC.

World Bank (2003). Global Development Finance, Washington, DC.

Wertheim, S. (1959). Sociological aspects of inter-island migration in Indonesia. Population Studies, 12, 184-201. 